\title{
Microalgal-based feed: promising alternative feedstocks for livestock and poultry production
}

\author{
Imen Saadaoui ${ }^{*}$ (D), Rihab Rasheed ${ }^{1}$, Ana Aguilar $^{2}$, Maroua Cherif ${ }^{1}$, Hareb Al Jabri ${ }^{1}$, Sami Sayadi ${ }^{1}$ and \\ Schonna R. Manning ${ }^{2}$
}

\begin{abstract}
There is an immediate need to identify alternative sources of high-nutrient feedstocks for domestic livestock production and poultry, not only to support growing food demands but also to produce microalgae-source functional foods with multiple health benefits. Various species of microalgae and cyanobacteria are used to supplement existing feedstocks. In this review, microalgae have been defined as a potential feedstock for domestic animals due to their abundance of proteins, carbohydrates, lipids, minerals, vitamins, and other high-value products. Additionally, the positive physiological effects on products of animals fed with microalgal biomass have been compiled and recommendations are listed to enhance the assimilation of biomolecules in ruminant and nonruminant animals, which possess differing digestive systems. Furthermore, the role of microalgae as prebiotics is also discussed. With regards to large scale cultivation of microalgae for use as feed, many economic trade-offs must be considered such as the selection of strains with desired nutritional properties, cultivation systems, and steps for downstream processing. These factors are highlighted with further investigations needed to reduce the overall costs of cultivation. Finally, this review outlines the pros and cons of utilizing microalgae as a supplementary feedstock for poultry and cattle, existing cultivation strategies, and the economics of large-scale microalgal production.
\end{abstract}

Keywords: Functional feed, High-value metabolite, Livestock production, Microalgae, Poultry product

\section{Introduction}

Production of animal feed can be an expensive process; thus, alternative economical high-quality ingredients are desired to supplement conventional feedstocks to meet the growing demands. Traditionally, microalgae have been used as a sustainable resource for domestic livestock, poultry and aquaculture production due to their diverse nutritional profiles, i.e., carbohydrates, essential fatty acids and amino acids, carotenoids, and vitamins $[1,2]$ Research has shown that blending a small portion of traditional feed with microalgae, e.g., Chlorella, Scenedesmus, and Arthrospira, can positively

\footnotetext{
* Correspondence: imen.saadaoui@qu.edu.qa

${ }^{1}$ Center for Sustainable Development, College of Arts and Sciences, Qatar University, P.O.Box.2713 Doha, Qatar

Full list of author information is available at the end of the article
}

affect the growth, health, overall animal physiology and product quality and quantity [3]. Moreover, it was stated that microalgae feed-supplement (i) presents cholesterol-lowering effect in animals, (ii) improves immune response [4], (iii) enhances milk quality and production yield in cows [5], (iv) promotes animal growth and improves meat and egg quality [6], (v) offers resistance to disease through antiviral and antibacterial action [7], (vi) improves gut function [8], (vii) enriches the colonization of probiotics $[8,9]$ and increases feed conversion [10]. Furthermore, it was recently proved that algae-based feed increases reproductive performance and helps in weight control [11].

The use of microalgae as feed supplement is currently being practiced in many Asian countries, including Japan, the Philippines, China, and Korea [12]. Authors reported that 
currently, there are several microalgae cultivation companies active in China for feed production. Additionally, such initiatives are also under way in Japan, Taiwan, Thailand and India, which are at present in their research and development phase and are increasing in size and number. The use of microalgal feedstocks has also spread to the United States and the United Kingdom [8, 13] In fact, around 30\% of the world's microalgal biomass production is presently sold for animal feed applications $[14,15]$. Thus far, more than 30,000 to 40,000 different strains of microalgae have been isolated and classified [16-18], and it is expected that many more will be discovered for potential use in feed. However, there is a long way to go before the production of microalgae-based feed sustainable and economically feasible.

The increasing interest in using microalgae as feed has led to a rise in the research activities and related publications in this field. However, the focus has been on specific applications such as aquafeed of poultry or animal feed. The current paper presents a broad spectrum of various applications which utilize microalgae as feed in poultry and livestock, highlighting several interesting microalgae metabolites with their nutritional and health benefits. Additionally, several challenges and limitations affecting the efficient use of microalgal biomass for feed purpose are also presented and discussed. Furthermore, this literature review considers the economic feasibility of the microalgal feed production based on its cultivation and product value. Hence, providing a comprehensive study of all the parameters included in the process. The review also presents a case study on Qatar, an emerging economy, that needs local alternatives such as microalgae to achieve self-sufficiency on food products.

\section{Microalgal compounds}

Microalgae are photosynthetic microorganisms that consume atmospheric $\mathrm{CO}_{2}$ and light energy to produce a variety of proteins, carbohydrates, and lipids, as well as microelements including, minerals, vitamins, polyphenols, flavonoids, and carotenoids [19, 20] (Fig. 1). The biochemical profiles of the microalgae species commonly used for producing animal feed such as Arthrospira platensis, Dunaliella salina, Hematococcus pluvialis, Chlorella sp., Nannochloropsis granulate and Tetraselmis chui, are presented in the Table 1. microalgae are highly dynamic and vary widely among strains due to differences in growth conditions such as temperature, geographical location, availability of sun light, etc. In addition to known metabolites, microalgae represent a resource of unexploited compounds, that may have unique properties and interesting applications, including but not limited to lipoproteins, sterols and alkaloids [29-31]. These molecules possess several health benefits such as boosting the immune system, which will eventually reduce the use of antibiotics for livestock poultry farming and aquaculture [10, 32, 33].

\section{Protein}

Finding multiple and novel alternative sources of proteins can be of great importance for food security purposes [34]. Different sources of proteins have been consumed in the last decade as food and feed. However, the overuse of such sources has led to the increasing awareness about finding novel alternatives to overcome the protein shortage risk [14]. Microalgae can be considered as a very promising alternative. Some strains of microalgae produce high amounts of protein and could

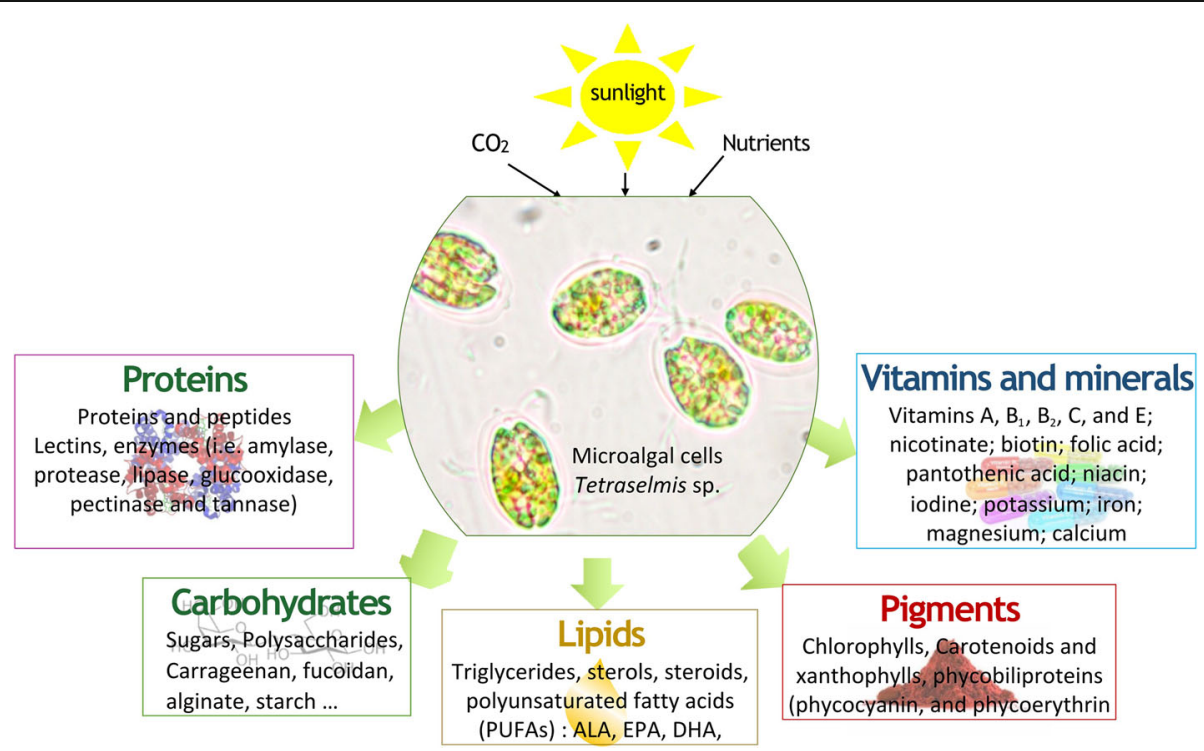

Fig. 1 Microalgae metabolites produced during photosynthetic activity 
Table 1 Notional properties of the microalgae species commonly used for feed

\begin{tabular}{lllllll}
\hline Microalgae species & $\begin{array}{l}\text { A. platensis, } \\
\text { \% of DW }\end{array}$ & $\begin{array}{l}\text { D. salina, } \\
\text { \% of DW }\end{array}$ & $\begin{array}{l}\text { H. pluvialis, } \\
\text { \% of DW }\end{array}$ & $\begin{array}{l}\text { Chlorella, } \\
\text { \% of DW }\end{array}$ & $\begin{array}{l}\text { Nannochloropsis granulata, } \\
\text { \% of DW }\end{array}$ & $\begin{array}{l}\text { Tetraselmis chui, } \\
\text { \% of DW }\end{array}$ \\
\hline Crude protein, \% & $51.4-67$ & $10-30$ & $29-45$ & $20-60$ & $26-33.5$ & 46.5 \\
Crude fat, \% & $1.8-7.3$ & $10-20$ & $20-25$ & $13.3-20.9$ & $15.3-23.6$ & 12.3 \\
Crude Carbohydrates, \% & 12.5 & $250-80$ & $15-17$ & $18.1-27.5$ & $32-36.2$ & 25 \\
Fibre (Total Dietary Fiber), \% & 1.0 & $9-11$ & $34-58$ & $16-35$ & 17.67 & - \\
\% Amino acids & & & & & &
\end{tabular}

Essential Amino acids

\begin{tabular}{|c|c|c|c|c|c|c|}
\hline Threonine & $2.9-4.9$ & 7.3 & 5.47 & 2.5 & 5.4 & 4.0 \\
\hline Valine & $4.2-4.6$ & 6.3 & 2.45 & 3.0 & 7.1 & \\
\hline Methionine & $1.2-1.6$ & 2.1 & 0.65 & 1.2 & 3.5 & \\
\hline Isoleucine & $4.2-4.4$ & 5.7 & 4.32 & 2.0 & 5.6 & \\
\hline Leucine & $5.5-8.0$ & 7.3 & 3.64 & 4.7 & 11 & \\
\hline Phenylalanine & $3.0-5.8$ & 11.5 & 1.4 & 2.7 & 6.2 & \\
\hline Histidine & $1.5-2.7$ & 2.6 & 0.31 & 2.2 & 2.3 & \\
\hline Lysine & $2.9-3.0$ & 2.1 & 2.68 & 4.0 & 8.5 & \\
\hline Arginine & $4.0-4.9$ & 2.6 & 10.26 & 3.1 & 7.4 & \\
\hline Tryptophane & $0.1-2.5$ & 2.6 & - & 1.0 & 2.8 & \\
\hline \multicolumn{7}{|c|}{ Jon-Essential amino acids } \\
\hline Asppartic acid & $2.4-9.2$ & 18.2 & 5.01 & 4.7 & 11.4 & \\
\hline Glutamic acid & $5.7-10.7$ & 10.4 & 10.41 & 5.8 & 5.6 & \\
\hline Serine & $2.8-4.3$ & 0.5 & 3.43 & 1.0 & 14.1 & \\
\hline Proline & $2.0-4.0$ & 1.0 & 1.24 & 2.5 & 11.2 & \\
\hline Glycine & $1.8-5.2$ & 9.4 & 6.61 & 3.4 & 7.5 & \\
\hline Alanine & $5.4-6.5$ & 7.3 & 5.6 & 4.6 & 7.1 & \\
\hline Cysteine & $0.4-0.5$ & 2.1 & 0.25 & 0.7 & 1.6 & \\
\hline Tyrosine & $3.2-3.3$ & 1.0 & 2.22 & 2.4 & 4.2 & \\
\hline
\end{tabular}

Fatty Acids, g/kg

$\begin{array}{llllll}\text { ALA } & - & 21.19 & - & - & - \\ \text { EPA } & <2.5 & - & 0.6 & <4.0 & 34 \\ \text { DHA } & <3.0 & - & 12.8 & <26.0\end{array}$

Elemental Composition

Minerals, \%

$\begin{array}{lllllll}\text { Calcium } & 1.3-14.0 & 2.10 & 0.25 & 0.1-5.9 & 0.09 & 2.99 \\ \text { Phosphorous } & 1.2-9.6 & 1.58 & 1.31 & 9.6-17.6 & 0.73 & 1.46 \\ \text { Potassium } & 6.4-16.6 & 4.32 & 0.97 & 0.5-21.5 & & 0.43 \\ \text { Magnesium } & 2.0-3.2 & 1.37 & 0.22 & 3.6-8.0 & 0.26 & 191 \\ \text { Trace elements, mg/kg } & & & & & & - \\ \text { Manganese } & 0.02-0.04 & - & 111.9 & 0.02-0.10 & 453 & 0.5 \\ \text { Natrium } & 4.5-10.5 & 35.4 & 58.7 & 13.5 & - & - \\ \text { Iron } & 0.5-1.8 & 4.5 & 822 & 0.4-5.5 & <\text { LD } & 0.5 \\ \text { Zinc } & 0.02-0.04 & - & 232 & 0.5 & 0.5 & 102 \\ \text { Selenium } & - & - & - & - & 0.5 & 17.8 \\ \text { Copper } & - & & & -5-80 & 10-60 & \end{array}$


Table 1 Notional properties of the microalgae species commonly used for feed (Continued)

\begin{tabular}{|c|c|c|c|c|c|c|}
\hline Microalgae species & $\begin{array}{l}\text { A. platensis, } \\
\% \text { of DW }\end{array}$ & $\begin{array}{l}\text { D. salina, } \\
\% \text { of DW }\end{array}$ & $\begin{array}{l}\text { H. pluvialis, } \\
\% \text { of DW }\end{array}$ & $\begin{array}{l}\text { Chlorella, } \\
\% \text { of DW }\end{array}$ & $\begin{array}{l}\text { Nannochloropsis granulata, } \\
\% \text { of DW }\end{array}$ & $\begin{array}{l}\text { Tetraselmis chui, } \\
\% \text { of DW }\end{array}$ \\
\hline \multicolumn{7}{|l|}{ Vitamin, mg/kg } \\
\hline Vit $B_{9}$ & 0.9 & & & 269 & - & - \\
\hline Vit $B_{1}$ & $5-50$ & & & $15-24$ & 70 & 1.09 \\
\hline Vit $B_{6}$ & $4-50$ & & & $10-17$ & 3.6 & 5.8 \\
\hline Vit E & 50-190 & 153.2 & & 200 & 0.29 & 1.57 \\
\hline Vit $B_{12}$ & - & $42-49$ & & - & 1.7 & - \\
\hline Ash, \% & $5.8-9.4$ & 48 & $4-29$ & $6.2-7.3$ & 8 & 16.2 \\
\hline Reference & {$[6,21,22]$} & [23-25] & {$[23,26-28]$} & {$[6,23]$} & {$[19,23]$} & [19] \\
\hline
\end{tabular}

be a potential renewable resource for feed supplements [31, 32], e.g., Cyanobacterium Arthrospira can contain up to $70 \%$ protein. Microalgae present very similar essential amino acid profiling to that of superior vegetable proteins such as Soya bean [19, 35, 36]. According to FAO/WHO recommendation, Microalgae such as Chlorella and Arthrospira (Spirulina) are considered as sustainable source of proteins suitable for human consumption due to the presence of essential amino acids similar to those acquired from conventional protein sources such as soybean and egg (FAO/WHO, 1991). Feed stocks containing higher concentrations of methionine and lysine have been found to increase chicken breast and thigh muscles and improve the quality and quantity of meat. Microalgae also produce bioactive peptides with antioxidative, antihypertensive, anticoagulative, antitumor and immune-simulative properties [11, 36]. The most widely used microalgae for protein-rich feed supplements include species of Chlorella, Arthrospira, Dunaliella, Tetraselmis, Phaeodactylum, Skeletonema, and Scenedesmus [37, 38].

\section{Carbohydrates}

Carbohydrates are a significant component of microalgae due to their nutritional and pharmaceutical value. Indeed, beta-1-3-glucan, a type of soluble fiber, most importantly found in Chlorella sp., is an antioxidant that helps in lowering cholesterol levels in blood [37, 39]. Moreover, A promising microalgae for the commercial production of carbohydrates is the unicellular red alga Porphyridium cruentum, which produces a sulfated galactan exopolysaccharide and can replace carrageenan in the meat and dairy industry [40]. Xylose, mannose, glucose, galactose and rhamnose are the most common species dependent monosaccharides which can be obtained through the production of the microalgal polysaccharides [41]. Among these sugars, glucose is highly detected in several green microalgae species with $47-85 \%$ of the total carbohydrates [41]. However, mannose is detected in higher concentrations in diatoms reaching $45.9 \%$ per total carbohydrates in the case of Phaeodactylum tnicornutum.

\section{Lipids}

Several microalgae species have been considered as excellent source of dietary lipids. Depending upon the strain and culturing conditions, microalgae can produce up to $50 \%$ lipids (w/w) on a dry weight (DW) basis, and occasionally even more $[17,42]$. The long-chain fatty acid profile of some microalgae can be enriched with polyunsaturated fatty acids such as eicosapentaenoic acid (EPA), alpha-linolenic acid (ALA), arachidonic acid (AA), docosahexaenoic acid (DHA), and linoleic acid (LA) [43]. These omega fatty acids are essential and cannot be synthesized by humans and animals, thus they must be ingested and absorbed. Furthermore, DHA and EPA are known with a range of biological functionalities such as antioxidant and anti-inflammatory activities, improving mental health, reducing the risk of cardiac diseases like arrhythmia, stroke, rheumatoid arthritis, and high blood pressure $[20,44]$. Recent studies proved that supplementing infertile men with omega- 3 fatty acids resulted in a significant improvement in sperm motility and concentration of DHA in seminal plasma [45]. Several microalgae species are known to be good source of these essential fatty acids such as Isochrysis, Nannochloropsis, Tetraselmis and Arthrospira [46-48].

\section{Carotenoids}

Carotenoids provide nutritional, therapeutic, and antioxidant properties [49]. Carotenoids are typically used as food-coloring agents and there are around 200 carotenoids which can be sourced from microalgae. Among them, $\beta$-carotenes and astaxanthin represent the most commercially produced carotenoids [50-52]. Other carotenoids such as lutein, zeaxanthin and lycopene are lesser known despite their interesting nutritional value (Table 2). In poultry feeding trials, microalgal feedstocks enriched with $\beta$-carotene led to a dark-yellow color of the yolk [60]. While microalgal carotenoids are more 
Table 2 Common carotenoids found in microalgae

\begin{tabular}{lll}
\hline Carotenoids & Microalgal Species & References \\
\hline B-carotene & Dunaliella salina and D.bardawil & {$[25]$} \\
Astaxanthin & $\begin{array}{l}\text { Haematococcus pluvialis, Chlorella } \\
\text { zofingiensis }\end{array}$ & {$[26]$} \\
Lutein & Scenedesmus almeriensis & {$[25]$} \\
Canthaxanthin & Chlorella zofingiensis & {$[52]$} \\
Lycopene & Chlorella marina & {$[53]$} \\
Fucoxanthin & Phaeodactylum tricornutum & {$[54]$} \\
Zeaxanthin & Microcystis aeruginosa & {$[55]$} \\
Alloxanthin & Cryptomonar ovata & {$[56]$} \\
Antheraxanthin & Chrysophaera magna & {$[57]$} \\
Violoxanthin & Chlorella vulgaris, Scenedesmus & {$[58]$} \\
neoxanthin & quadricauda, Neochloris oleoabundans, C. & \\
& protothecoides & {$[59]$} \\
Peridinin & Dinophyta &
\end{tabular}

expensive than synthetic forms, natural sources provide more isomers [60]. Dunaliella salina is commonly used for $\beta$-carotene production, since they can accumulate up to $14 \%$ of their weight as $\beta$-carotene, under extreme conditions such as hypersaline, low nitrogen, and high levels of solar irradiation [13, 61, 62]. Similarly, strains of Haematococcus pluvialis produce up to $4-5 \%$ astaxanthin, including free, mono-, and di-ester forms, under stressed conditions $[23,26,63]$.

\section{Vitamins and minerals}

Microalgal biomass represents a valuable resource for many essential vitamins and could be used to supplement feed stocks [64]. These include vitamin $A$ and other retinoids, $B$ vitamins like thiamine $\left(B_{1}\right)$, niacin $\left(B_{2}\right)$, nicotinate $\left(B_{3}\right)$, pantothenic acid $\left(B_{5}\right)$, pyridoxal phosphate $\left(B_{6}\right)$, biotin $\left(B_{7}\right)$, folic acid $\left(B_{9}\right)$ and cobalamin $\left(B_{12}\right)$, vitamin $C$ (ascorbic acid), vitamin $E$ (tocopherols), and a variety of trace metals and minerals (e.g. sodium, potassium, calcium, magnesium, iron, and zinc) $[6,8,65]$ Microalgae also synthesize vitamins and accumulate minerals in their natural forms so that they can be easily assimilated, when compared to synthetic forms [66]. The synthesis of vitamins depends on the strain, light intensity, nutrients available in the media, and stage of the growth cycle, among other factors. Strains of Tetraselmis sp. have shown high amounts of thiamine, pyridoxine, nicotinic acid, and pantothenic acid, whereas strains of Dunaliella contained elevated amounts of $\beta$-carotene, riboflavin, and cobalamin. Some isolates of Chlorella were found to contain abundant levels of tocopherol and biotin [64] (Table 1).

\section{Nutritional potential of microalgae-based feed Microalgae for animal feed}

Microalgae can be the next alternate source for animal and aquatic feed production in an environmentally sustainable and nutritionally beneficial manner [15]. These microorganisms can be produced in large scale using photobioreactors and open ponds then harvested and processed to produce functional feed supplements for different animals such as poultry, pigs, sheep and mink [67, 68]. The Fig. 2 represents the technology process lineup for producing high quality algae-based feed for animal-sourced functional foods. Altering the cultivation conditions can make the feed beneficial, since it can be enriched with highly valuable metabolites such as omega fatty acids, carotenoids and essential amino acids [11, 50, 69, 70]. Consequently, the enriched microalgae can be used as feed supplement to improve the quality of their meat, eggs and milk products which will provide multiple health benefits such as anticancer, antioxidant and antiviral effects to humans when consumed [20, 71, 72] (Table 3).

\section{Microalgae feed supplement for eggs production}

Literature related to the manipulation of polyunsaturated fatty acids (PUFAs) in the diet is extensive, which has led to the production of customized egg yolks that are rich in PUFAs to meet desirable nutritional characteristics [74, 75]. Microalgae are an alternative feedstocks for essential omega-3 fatty acids ( $\omega-3$ FAs) to improve the nutritional value of eggs for human consumption [76]. Many $\omega-3$ FAs have potent antiinflammatory properties that are essential for brain development and maintenance, as well as for the prevention of cardiovascular disease. Laying hens fed with diets supplemented with Nannochloropsis gaditana, containing long-chain $\omega-3$ FAs, such as eicosapentaenoic acid (EPA), docosapentaenoic acid (DPA), and docosahexaenoic acid (DHA), resulted in the accumulation of these $\omega-3$ FAs in the egg yolk [77]. The abundance of $\omega-3$ FAs in eggs varies with chicken age and breed, and microalgae digestibility $[75,78]$.

Eggs from hens that were fed with algal-blended feedstocks enriched with $\omega-3$ FAs contained more beneficial fatty acids when compared to eggs produced from conventional feed [79]. These long-chain fatty acids are almost exclusively located in the phospholipids of the yolk. In feed trials, very small quantities of microalgal biomass added to feedstocks yielded significant changes in the $\omega-3$ FA content of eggs. Additionally, Herber and Van Elswyk [80] and Moran et al., [81] demonstrated that the efficiency of DHA assimilation from microalgae to eggs was $42.6 \%$ in hens when they were provided with a $2.4 \%$ algal-blended feed. Compared to the control eggs, the DHA content increased 6-fold in eggs from hens fed 


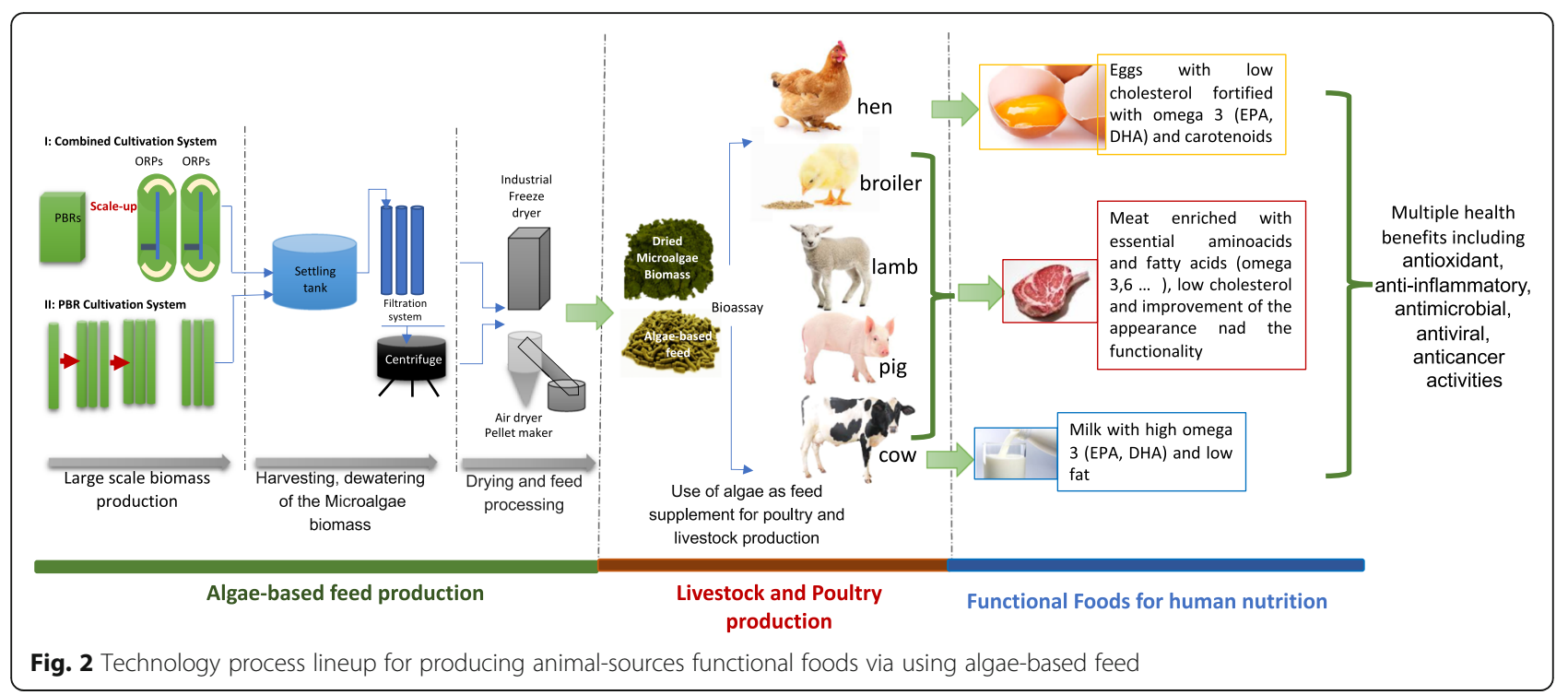

with algae-based feed [76]. Feedstocks high in EPA with trace levels of DHA (as is found with Nannochloropsis oculata) tend to produce eggs that are low in EPA and high in DHA, indicating fatty-acid chain elongation of EPA to DHA or the preferential bio-assimilation of DHA over EPA. It is noteworthy that, chickens supplemented with algal feedstocks such Porphyridium sp. consumed $10 \%$ less feed than the control groups, and the egg yolks had reduced cholesterol levels and lower ratios of $\omega-6: \omega-3$ FAs [82]. Omega-rich feedstocks comprised of $2.5 \%$ dried-fermented Schizochytrium sp. blended with flax seeds yielded $150 \mathrm{mg}$ of $\omega$-3 FAs/egg [83]. While seedstocks containing substantially high levels of $\omega-3$ FAs have no adverse effects on the performance or health of the bird, it should be noted that omega-rich feedstocks can cause a decrease in the tocopherols necessary for proper egg yolk formation and oxidative stability [84]. It is reported that micro algal inclusion as low as $1.5 \%$ to $10 \%$ is beneficial for broilers, beyond which the growth and quality of eggs will be negatively affected [79].

Fredriksson et al. [79] tested the addition of $20 \% \mathrm{Nan-}$ nochloropsis oculata in hen feedstocks. In their examinations, the lutein and zeaxanthin content of the eggs was approximately $1.3 \mathrm{mg} / \mathrm{egg}$ after 4 weeks of feeding hens a diet supplemented with microalgae. Egg yolks with higher concentrations of carotenoids often appeared dark orange to red [85]. Both synthetic carotenoids (e.g., Carophylls) and natural carotenoids can significantly increase the egg weight and improve feed conversion. However, naturally-occurring lutein in Chlorella-supplemented feedstocks was found to be incorporated more efficiently and significantly increased the oxidative stability of yolk lipids [86]. Furthermore, diets rich in carotenoids improved eggshell thickness and other desirable physical properties.

\section{Microalgae for meat quality}

Omega-3 fatty acids are considered essential because humans and livestock lack the ability to synthesize them, and they must be obtained through diet. The health benefits of PUFAs, including ALA, EPA, and DHA have been well documented [87]. Consequently, it has been suggested that consuming foods with significant amounts of $\omega-3$ PUFAs can have significant health benefits and these compounds have high commercial potential [88].

A high percentage of PUFAs are bio-hydrogenated in the rumen if the feedstocks are unprotected (i.e., uncoated). The diet of ruminant animals is based on cereals or forage known to be rich in linoleic acid (LA, C18:2 n-6) and ALA (C18:3 n-3) [89], although very low

Table 3 Bioavailable energy values of algae-based feed for livestock and poultry

\begin{tabular}{|c|c|c|c|c|c|}
\hline $\begin{array}{l}\text { Algae species used for animal } \\
\text { feed }\end{array}$ & Animal & $\begin{array}{l}\text { ME (metabolizable } \\
\text { energy) }\end{array}$ & $\begin{array}{l}\text { Net energy } \\
\text { (NE) }\end{array}$ & $\begin{array}{l}\text { Ileal Digestibility Coefficient for } \\
\text { essential AA }\end{array}$ & Reference \\
\hline Schizochytrium spp. & Cow & $3.48 \mathrm{Mcal}$ & - & - & [73] \\
\hline Arthrospira platensis (Spirulina) & $\begin{array}{l}\text { Broiler } \\
\text { Chicken }\end{array}$ & $13.48 \mathrm{MJ} / \mathrm{kg} \mathrm{DM}$ & $18.4 \mathrm{MJ} / \mathrm{kg}$ & $0.80 \pm 0.04 \mathrm{MJ} / \mathrm{kg} \mathrm{DM}$ & [21] \\
\hline Arthrospira platensis & Poultry & 3.48 Mcal & - & - & [22] \\
\hline
\end{tabular}


concentrations of these PUFAs were observed in the ruminant meat [90]. In fact, about $70-95 \%$ of LA and $85-100 \%$ of ALA are bio-hydrogenated before leaving the rumen $[90,91]$. Several strategies have been adopted to enrich meat with PUFAs, especially EPA and DHA, such as supplementing conventional animal feed with fish, marine microalgae, and algae-like microorganisms. Such bioassays proved that the algal-based feed supplement was the best at enhancing EPA and DHA levels in the animal meat. On the other hand, Elmore et al. [92] proved that using linseed and fish oils as feed supplements improved the meat quality in Suffolk and Soya lambs by doubling the amount of ALA and increased EPA and DHA at 2- and 4-fold, respectively.

It has been shown that mixing one or more PUFArich algal species such as Arthrospira maxima and Arthrospira platensis, or Chlorella sp. into the diet of pigs produced meat with a well-balanced lipid profile [36, 93]. More recently, it was proved that using microalgae, such as Schizochytrium sp., as feed stock, with an inclusion percentages of $5 \%$ and $7 \%$, used for growing pigs enhanced the omega 3 fatty acid content in their meat with inducing changes in skeletal muscle, phenotypic appearance and functionality [94]. In a different study, it was shown that including microalgae in the diets of weanling pigs by up to $33 \%$, which is so far, the highest amount recorded, did not affect them negatively. However no weight gain was also reported [95].

In the case of poultry meat, it was previously described by Toyomizu et al. [96] that supplementing of the conventional poultry feed with Arthrospira (4\% or $8 \%$ ), did not show any effect on the growth performance of the broilers but it led to the yellowness of muscles, skin, fat and liver, which adds to commercial value of the meat in the market. However, supplementing poultry feed with fresh liquid algae (1\%) improves the body weight gain, immune characteristics, and production of Lactobacillus bacteria in the intestinal microflora of broiler chickens [97]. Finally, defatted biomass of Chlorella and Arthrospira obtained from biofuel production showed positive effect on poultry meat quality [98].

\section{Microalgae for milk production and quality}

Increasing research exists on the use of microalgae as a dietary supplement for the accumulation of beneficial fatty acids in milk $[5,73,99-101]$. However, the effects of microalgal metabolites on lactation and the transfer of nutrients to the milk largely depends on the animal's digestive system (ruminant vs. non-ruminant) as well as the biosynthetic capabilities of the animal [5]. In case of ruminants, the nature of enzymes in the small intestine and the rumen microorganisms, have an impact on the digestion and absorption of fatty acids from the intestine. The intestinal and microbial enzymes break down the unsaturated fatty acids into short chain saturated fatty acids for absorption, resulting in the modification of the nature of molecules that will be incorporated into the animal tissue. While in non-ruminant animals, dietary fatty acids are unchanged and can be absorbed by the small intestine and incorporated directly into tissues.

It has been demonstrated that milk quality is strictly influenced by the type and abundance of fatty acids consumed by cattle, thus bio-hydrogenation in the rumen must be prevented [102]. It has recently been proved that microalgae are likely comparable protein feed to soya bean meal in dairy cattle nutrition [99]. Thus, it is recommended to use coated microalgae biomass to protect the nutritional properties of the feedstock in ruminant animals, allowing more $\omega-3$ FAs to be absorbed by the small intestine which will then be transferred to the mammary glands [103]. Additionally, blended algal feedstocks have shown to increase the abundance of LA, DHA, and vaccenic acids in the milk fat $[99,104,105]$.

Microalgae supplementation has shown to increase the DHA content up to 4 times in milk [106]. The most commonly used microalgae strains for improving the quality of milk in terms of useful fatty acids are Schizochytrium and Nannochloropsis [101, 104]. Additionally, Nannochloropsis sp. has also showed a higher content of EPA along with other PUFAs [107], in comparison with strains such as Arthrospira platensis (cyanobacterium) and $C$. vulgaris [42], showing EPA contents high as fish oil $[99,108]$. Such findings state that microalgae belonging to different genera differ in their biochemical profiles and will have different effects on animals when used as feedstocks.

Despite the increased quantities of LA, EPA, and DHA in milk enriched with $\omega-3$ FAs, the oxidative stability of the milk remains unchanged [106, 109]. In addition, feeding $\omega-3$ FAs during lactation was found to reduce prostaglandin secretion, which can improve fertility and embryo survival [100]. Additionally, incorporating microalgae at 5-10\% inclusion rates while feeding livestock, enhances the mineral content such as for Iron, Iodine, potassium and zinc found in the milk and meat of the animals [65]. Finally, Glover et al. [106] demonstrated the rumenprotected microalgae reduced total milk solids $(12.57 \%$ vs. $13.19 \% \pm 0.17 \% ; P=0.02)$ and the milk-fat content $(3.99 \%$ vs. $4.70 \% \pm 0.17 \% ; P=0.007$ ). The urea content in milk was also lower for cows fed protected microalgae (2.98 $\mathrm{mg} / \mathrm{dL}$ vs. $3.22 \pm 1.27 \mathrm{mg} / \mathrm{dL} ; P=0.01$ ).

\section{Microalgae as prebiotics}

Prebiotics prevent pathogen invasion in the body via boosting the immune system, resulting in enhancing the animal's health [110]. The most promising feed ingredient conferring prebiotic properties are polysaccharides or their derivatives, which include the dietary fibers [111]. 
Currently, large number of microalgae presenting prebiotic effect are being used in feed industry. Chlorella sp. produced an acidic polysaccharide containing rhamnose (52\%) along with arabinose and galactose. This complex is known to have immune-stimulating properties by inhibiting the proliferation of harmful pathogens [112]. Similarly, the cell walls of Tetraselmis sp. also consists of acidic polysaccharides ( $82 \% \mathrm{DW})$ favoring the gut microbiota. Another interesting microalga is Dunaliella salina, which reportedly produces extracellular polysaccharides known to have immunostimulatant, antiviral and antitumor properties [24]. Therefore, it is evident that microalgae not only improve the health and performance of animals by direct supply of nutrients, as discussed in the previous sections, but also benefit them indirectly, by promoting the intestinal microbiota that enhances the animal's health.

\section{Limitations of using microalgal feedstocks}

The current challenges in food industry are to find alternative sources of nutrients and additives that can add value to the agricultural products and protect them from oxidation. Researchers have successfully incorporated PUFAs into numerous foods [113, 114]. However, Shingfield et al. [91] proved that the accumulation of PUFAs can affect the flavor of the meat and milk in addition to the increased risk of oxidation. Lee et al. [114] also demonstrated that increasing PUFAs in meat affects its flavor and routine meat processing procedures (e.g., grinding and cooking) by intensifying lipid oxidation.

Moreover, milk and dairy products enriched with PUFAs are more susceptible to oxidation $[65,115]$ which can ultimately have an effect on the milk quality [115-117]. However, this can be slowed down by using antioxidants, including tocopherols and carotenoids, and thus preserve the quality of milk. Several investigations have demonstrated that an antioxidant combination, such as a radical quencher, chelator (e.g., sodium citrate), or reductant (e.g., sodium erythorbate) can be added as feed supplement to fortify the meat, minimizing lipid oxidation [114], enhance PUFA absorption, facilitate easy incorporation into tissues [88], while preserving the color of the meat, and maintain the concentration of PUFAs during storage [114].

The use of microalgae in feed provides the necessary nutrients such as PUFAs in addition to antioxidants such as carotenoids, for enriching and preserving food. However, selection of the microalgae species to produce the feed likely affects the animal performance as the species can significantly differ in terms of metabolic composition, protein degradability and cell wall composition [21]. Digestibility is affected by (i) the high fiber content in the cell wall [118], (ii) the high polysaccharides content reaching up to $64 \%$ of the DW with specific species and under specific cultivation conditions, and (iii) high phenolic compounds that can react with amino acids to form insoluble compounds [1] (Table 2). Hence, several methods have been recently optimized to treat the cell membrane in order to release the valuable intracellular contents [21]. Finally, it is also essential to identify the range of microalgae inclusion in the diet as performed by Evans et al. [119], where Arthrospira was tested in different proportions (6-21\%), positive impact on poultry meat was observed only with feed amended up to $16 \%$ microalgae. This could be explained by the low digestibility of high microalgae amounts in the diet [68]. More recently, 12 microalgae have been characterized for biochemical composition and "in vitro" digestibility. Results proved that Arthrospira and Chlorella sorokiniana with a high protein content between $50 \%$ and $65 \%$ exhibited the highest digestibility [22]. However, Tetraselmis strains rich in fibers and lipids showed the lowest digestibility. This was explained by the presence of robust cell walls or of exopolysaccharides that might have limited the action of digestive enzymes [22]. Additionally, Moheimani et al. [120] proved similar digestibility various combinations including ground, ground plus bead-milled, and ground plus bead-milled plus defatted microalgal biomass via "in vitro" assays. However, fermented Chlorella improve nutrient digestibility, fecal microbial shedding and the growth performance of 6 weeks old pigs when compared with the conventional diet. More recent research proved that poultry diet containing up to $16 \%$ of Arthrospira biomass lead to high digestibility of cysteine and lysine [119] (Table 3).

\section{Challenges and achievements in producing microalgal feedstocks \\ Cultivation and production of biomass}

The technologies needed for cultivation, harvesting, and processing/extraction are considered as leading factors contributing to the high costs of producing microalgal biomass [121]. The most common growth systems are open raceway ponds, tubular photobioreactors (PBRs), and flat-panel PBRs. The selection of a large-scale commercial culture system is dependent on several parameters such as cell biology, land availability, operating, production, harvesting and maintenance costs, energy and nutrient requirements, water availability and climate conditions [122]. Raceway ponds are typically shallow, ring-channel systems where cultures are mixed with a paddle wheel set at a fixed velocity. It was stated previously that open-pond systems generate low-density biomass, ranging from $0.3-0.5 \mathrm{~g} / \mathrm{L} \mathrm{DW}[123,124]$. While this technology uses much less energy for mixing cultures than the other reactor designs, higher costs are incurred for harvesting due to the low culture densities. Moreover, the cultures grown in this system are 
significantly affected due to external environmental factors such as temperature, $\mathrm{pH}$, light, salinity and pollution, which also explains the low productivity [125]. Sugar-stimulated $\mathrm{CO}_{2}$ sequestration by the green microalga Chlorella vulgaris [125]. Open ponds are used extensively in industrial microalgal production where huge volumes of culture (around 40,000 L in $200 \mathrm{~m}^{2}$ illuminated area) are maintained [126]. Such cultivation system generated an annual production of Arthrospira and Dunaliella biomass of 3,000 tons and 1,200 tons, respectively [37].

In tubular PBRs, algal cultures are circulated in semiclosed transparent glass or PVC piping without a centrifugal pump as this damage most algae cells [127]. Typically, biomass densities of greater than $1.7 \mathrm{~g} / \mathrm{L}$ DW can be obtained using tubular PBRs [124]. Tubular PBRs are commonly used for growing more controlled cultures of microalgae species with high nutraceutical potential such as Haematococcus, Chlorella, and Nannochloropsis [128]. A flat-panel PBR is a transparent, rectangular cuboid vessel in which mixing is carried out by sparging air directly into the reactor. This configuration resulted in biomass productivity of $15 \mathrm{~g} / \mathrm{m} / \mathrm{d}$ of Tetraselmis suecica corresponding to an annual yield of 36 tons of dry biomass per hectar [129]. Flat-panel PBRs are ideal for the production of algal strains that accumulate lipids under nutrient limitation stress with the shorter light path found in panel PBRs.

\section{Economic feasibility of microalgae production and market values}

Microalgal biomass has been proposed as a renewable resource for the generation of energy and other commodities due to their high rates of productivity. They can be grown using low quality water and do not require arable land $[62,91,130]$. Even so, production of microalgal biomass is more expensive when compared to other feedstocks, e.g., wheat sells for $\$ 0.035 / \mathrm{kg}$ [131]. Improvements in microalgal processing methods together with optimizing the cultivation and harvesting systems are needed to develop technical solutions that will improve the feasibility of cultivating microalgae for biomass and valuable compounds in a profitable means at commercial scale. Currently, the microalgal biomass market produces nearly $5 \mathrm{kt}$ per year and the production costs are around $\$ 25,000$ per ton of biomass from mainly five taxa [132] (Fig. 3).

Biomass recovery cost represents $20-30 \%$ to the total production costs $[121,133]$. Harvesting the biomass challenging because of the size of the microalgal cells, which range from 3 to $60 \mu \mathrm{m}$ in diameter. The microalgal biomass is typically dewatered and concentrated using centrifugation, filtration, or in some cases, gravity sedimentation, and each of the processes have different

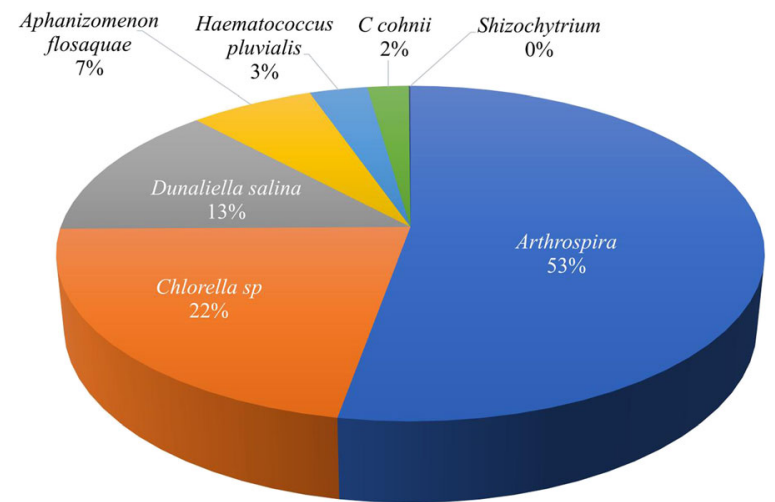

Fig. 3 Annual commercial production of the major genera of microalgae worldwide

energy demands. These processes may be preceded by a sedimentation step using caustics or flocculants (e.g., alum, chitinase, magnesium hydroxide) to preconcentrate the biomass for subsequent dewatering [134]. However, it was proved that the chemical flocculants can alter the quality of the final product and/or affect the biomass processing (lipid extraction) [135]. Unfortunately, there is no harvesting method that works for all types of microalgae, and this step must be determined empirically for each strain, including considerations for the application. The annual production of dry algae biomass was estimated of 19,000 tons, generating a revenue of about $\$ 5.7$ billion [31]. Although production estimates are available for only a few strains of microalgae that are cultivated at the commercial scale: the annual production of Arthrospira dominates the market (3000 tons /year) followed by Chlorella (2,000 tons/year) [27], Dunaliella (1,200 tons/year), Aphanizomenon (500-600 tons/year) and Haematococcus pluvialis (300 tons/year). This biomass is processed to generate a number of products that are used for various applications, including nutraceuticals, pharmaceuticals animal feed, aquaculture, human food, coloring substances and antioxidants. The global algae market is projected to reach $\$$ 1.143 billion by 2024 with an annual expansion rate of 7.39\%. Purified microalgal products, including $\omega$-FAs, antioxidants, and coloring agents, generate significantly more revenue than the unprocessed, whole biomass [28] (Fig. 4). For example: Microalgae such as Chlorella and Scenedesmus produce a variety of natural functional ingredients such as lutein [136]. The global market for lutein is expecting to reach $\$ 357.7$ million by 2022 . Similarly, the global market value for carotenoids reached up to $\$ 1.24$ billion in 2016 and is expected to reach $\$ 1.53$ billion by 2021 [137].

The potential for microalgae to supply the world market is very high although there are still gaps between current production capabilities and market demands. 


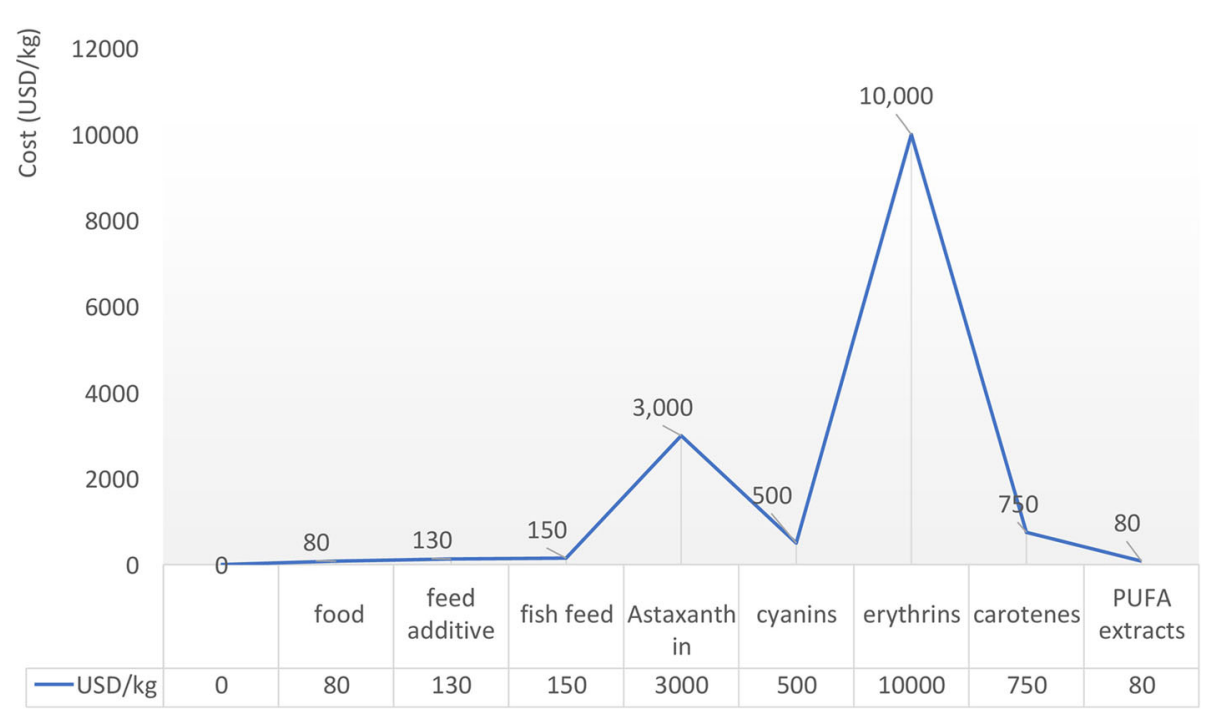

Fig. 4 High-value products from microalgae (in USD/kg) for various commercial uses

The high production cost of microalgae [138] makes them currently an uncompetitive feed option, but the situation may change in the near future due to technical development and different policy interventions such as incentives and carbon taxation. As per the prnewswire website (https://www.prnewswire.com/news/ reportlinker), global algae products market stood at \$ 9.9 billion in 2018 and is projected to grow at a Compound annual growth rate (CAGR) of over $7 \%$ during 2019-2024.

\section{Industrial scale production of microalgae for feed application}

Microalgae can be cultivated in different systems, depending upon the application of the biomass. For feed purposes, industrial bioreactors and open ponds are suitable [139]. Several studies have shown that microalgae cultivation for feed production at industrial scale is possible and can be achieved from a sustainability perspective. Biomass can be generated when cultivated on wastewater such as from fish processing industry, as explained by Trivedi et al. [140] where Chlorella vulgaris was effectively cultivated in untreated water from the industry without the addition of nutrients. It is, however, essential that the final biomass is free from pathogens, toxins and thus is safe for use as feed. In another scenario, sequestering atmospheric $\mathrm{CO}_{2}$ to produce microalgae biomass will benefit the environment in addition to improving the production of microalgae. In both the above cases, micro algal production will lead to a cleaner environment and use sustainable resources for growth. Considering the information available, despite the existing knowledge and facilities, use of microalgal products still faces some drawbacks in terms of technological and economical facets. This is, however, likely to be reversed due to its benefits and growing popularity as feed stock.

\section{Microalgae-based feed production: a case for Qatar}

The nutritional content of microalgae makes it a suitable alternative for feed supplement. However, the future use of microalgae in feed formulations depends on development of cost-effective strategies for large-scale production. This is especially important for growing populations that are reliant on imported food. The food market has been seriously challenged over the last few decades by the population growth in Qatar, a country that is overwhelmingly reliant on imported food, which can represent up $90 \%$ of the population's needs - this is neither economically-feasible nor sustainable. Furthermore, regional food production is limited due to arid climate, availability of arable land, and the scarcity of fresh water. Thus, there is an immediate need to identify alternative sources of food to sustain the population of Qatar and meet growing demands.

A country like Qatar, which is located on a peninsula with abundant sunshine, favorable temperatures for cultivation, and access to plenty of water, may be able to co-locate and utilize local resources, thus bringing down the costs of producing microalgal biomass for nutritional feed supplements. Microalgae are already used in many applications in Qatar, including for biofuels, feed, biofertilizers, waste water management, and $\mathrm{CO}_{2}$ sequestration [141-147]. The use of microalgae-based foods has gained interests over the last few years, supporting the possibility of using microalgae for supplementing local poultry and livestock to produce enriched animal products for human consumption. Although, as with any 
case, a technoeconomic analysis would need to be performed, looking at broad suite of variables, to determine economic feasibility.

\section{Conclusion}

Microalgae have tremendous potential as animal feed due to the presence of essential biomolecules such as amino acids, PUFAs and high-value products such as carotenoids and vitamins, that enhance the nutritional quality of the animal products. Consequently, serving as a sustainable source of nutrition for animals. Although these microorganisms are considered as the most suitable alternative, there are certain limitations in using them. Digestibility and selection of the right inclusion dose is some of the challenges that should be addressed with regards to the animal feed. Additionally, the economic feasibility of producing large amounts of biomass for feed is ambiguous due to high production costs, downstream processing, and storage issues. These issues need to be addressed in order for the microalgal feedstock to be cheaper than the existing agricultural products. Since the demand of microalgal biomolecules is growing in the market, more research should be directed towards the cultivation strategies, for identification of sustainable and economical production of biomass for the usage as animal feed and therapeutics.

\section{Abbreviations}

A. platensis: Arthrospira platensis; Aa: Aminoacids; AA: Arachidonic acid; ALA: Alpha-linolenic acid; C. cohnii: Crypthecodinium cohnii; C. vulgaris: Chlorella vulgaris; CAGR: Compound annual growth rate; D. salina: Dunaliella salina; DHA: Docosahexaenoic acid; DPA: Docosapentaenoic acid; DW: Dry weight; EPA: Eicosapentaenoic acid; FA: Fatty acid; FAO: Food and Agriculture Organization; LA: Linoleic acid; ME: Metabolizable energy; NE: Net energy; Pbr: Photobioreactors; PUFAS: Polyunsaturated fatty acids; PVC: Polyvinyl chloride; Vit: Vitamin; WHO: World Health Organization; $\omega-3$ FAs: Omega 3 fatty acid

\section{Acknowledgements}

Special thanks go to the Centre for Sustainable Development for the kind support.

\section{Authors' contributions}

I.S: Conceptualization, writing—original draft preparation, writing—review and editing and funding acquisition; R.R. and A.A. writing - original draft preparation, M.C; S.S. and H.A.J. writing-review and editing, S.M. Conceptualization, writing —original draft preparation and, writing-review and editing. The author(s) read and approved the final manuscript.

\section{Funding}

This report was made possible the NPRP award [NPRP8-1087-1-207] from the Qatar National Research Fund, a member of The Qatar Foundation. The statements made herein are solely the responsibility of the authors. Open Access funding provided by the Qatar National Library.

Availability of data and materials

Not applicable.

\section{Declarations}

Ethics approval and consent to participate Not applicable.
Consent for publication

Not applicable.

\section{Competing interests}

The authors declare that they have no competing interests.

\section{Author details}

${ }^{1}$ Center for Sustainable Development, College of Arts and Sciences, Qatar University, P.O.Box.2713 Doha, Qatar. ${ }^{2}$ Department of Molecular Biosciences, UTEX Culture Collection of Algae, University of Texas at Austin, Austin, TX 78712 , USA.

Received: 19 December 2020 Accepted: 6 April 2021

Published online: 17 June 2021

\section{References}

1. Safafar H, Van Wagenen J, Møller P, Jacobsen C. Carotenoids, phenolic compounds and tocopherols contribute to the antioxidative properties of some microalgae species grown on industrial wastewater. Mar Drugs. 2015; 13(12):7339-56. https://doi.org/10.3390/md13127069.

2. Ljubic A, Jacobsen C, Holdt SL, Jakobsen J. Microalgae Nannochloropsis oceanica as a future new natural source of vitamin D3. Food Chem. 2020; 320:126627. https://doi.org/10.1016/j.foodchem.2020.126627.

3. Kotrbáček V, Doubek J, Doucha J. The chlorococcalean alga Chlorella in animal nutrition: a review. J Appl Phycol. 2015;27(6):2173-80. https://doi. org/10.1007/s10811-014-0516-y.

4. RajaR, Hemaiswarya S. Microalgae and Immune Potential. In: WatsonRR, Zibadi S, PreedyVR, editors. Diet Components Immune Funct. London: Springer; 2010. p. 515-27.

5. Altomonte I, Salari F, Licitra R, Martini M. Use of microalgae in ruminant nutrition and implications on milk quality - a review. Livest Sci. 2018;214: 25-35. https://doi.org/10.1016/j.livsci.2018.05.006.

6. Madeira MS, Cardoso C, Lopes PA, Coelho D, Afonso C, Bandarra NM, et al. Microalgae as feed ingredients for livestock production and meat quality: a review. Livest Sci. 2017;215:111-21.

7. DewilC, Falaise C, Hellio C, Bourgougnon N, Mouget JL. Anticancer,antiviral, antibacterial,and antifungal properties in microalgae. In: Levine, IA, Fleurence J,Editors. Microalgae Heal Dis Prev. Cambridge: AcademicPress; 2018. p. 235-61.

8. Camacho F, Macedo A, Malcata F. Potential industrial applications and commercialization of microalgae in the functional food and feed industries: a short review. Mar. Drugs. 2019;17(6):312. https://doi.org/10.3390/md1 7060312.

9. Verschuere L, Rombaut G, Sorgeloos P, Verstraete W. Probiotic Bacteria as biological control agents in aquaculture. Microbiol Mol Biol Rev. 2000;64(4): 655-71. https://doi.org/10.1128/MMBR.64.4.655-671.2000.

10. Tibbetts SM. The potential for 'next-generation', microalgae-based feed ingredients for salmonid aquaculture in context of the blue revolution. Microalgal Biotechnol. 2018. https://doi.org/10.5772/intechopen.73551.

11. Navarro F, Forján E, Vázquez $M$, Montero Z, Bermejo E, Castaño MÁ, et al. Microalgae as a safe food source for animals: nutritional characteristics of the acidophilic microalga Coccomyxa onubensis. Food Nutr Res. 2016;60(1): 30472. https://doi.org/10.3402/fnr.v60.30472

12. Chen J, Wang Y, Benemann JR, Zhang $X$, Hu H, Qin S. Microalgal industry in China: challenges and prospects. J Appl Phycol. 2016;28(2):715-25. https:// doi.org/10.1007/s10811-015-0720-4.

13. Novoveská L, Ross ME, Stanley MS, Pradelles R, Wasiolek V, Sassi JF. Microalgal carotenoids: a review of production, current markets, regulations, and future direction. Mar Drugs. 2019;17(11):640. https://doi.org/10.3390/ md17110640.

14. Becker W. Microalgae for Aquaculture: The Nutritional Value of Microalgae for Aquaculture. In:Rechmond A, editor. Handbook of Microalgal Culture: Biotechnology andApplied Phycology. TheOxford: Blackwell Publishing; 2007. p. 380-91.

15. DineshbabuG, Goswami G, Kumar R, Sinha A, Das D. Microalgae-nutritious, sustainable aqua- and animal feed source. J Funct Foods. 2019;62:103545.

16. Sime I. The freshwater algal flora of the British Isles: an identification guide to freshwater and terrestrial algae, edited by David M. John, Brian a. Whitton and Alan J. brook. Cambridge University press, Cambridge, 2002, 702pp. ISBN 0-521-77051-3. Aquat Conserv Mar Freshw Ecosyst. 2004;14(1): 105. https://doi.org/10.1002/aqc.579. 
17. Mata TM, Martins AA, Caetano NS. Microalgae for biodiesel production and other applications: a review. Renew Sust Energ Rev. 2010;10:217-32.

18. Islam MA, Heimann K, Brown RJ. Microalgae biodiesel: current status and future needs for engine performance and emissions. Renew Sust Energ Rev. 2017;17:1160-70

19. Tibbetts SM, Milley JE, Lall SP. Chemical composition and nutritional properties of freshwater and marine microalgal biomass cultured in photobioreactors. J Appl Phycol. 2015;27(3):1109-19. https://doi.org/10.1 007/s10811-014-0428-x

20. Barkia I, Saari N, Manning SR. Microalgae for high-value products towards human health and nutrition. Mar Drugs. 2019;17(5):304. https://doi.org/10.33 90/md17050304

21. Tavernari F, Roza LF, Surek D, Sordi C, Da S, Albino L, et al. Apparent metabolisable energy and amino acid digestibility of microalgae Spirulina platensis as an ingredient in broiler chicken diets. Br Poult Sci. 2018;59:562-7.

22. Niccolai A, Venturi M, Galli V, Pini N, Rodolfi L, Biondi N, et al. Development of new microalgae-based sourdough "crostini": functional effects of Arthrospira platensis (spirulina) addition. Sci Rep. 2019;9(1):19433. https://doi. org/10.1038/s41598-019-55840-1.

23. Borowitzka MA. Carotenoid Production Using Microorganisms. In:Cohen, Z Ratledge, C,editors. Single Cell Oils Microb Algal Oils Second. Illinois: AOCS Press; 2010. p. 225-240.

24. Harvey PJ, Ben Amotz A. Towards asustainable Dunaliella salina microalgal biorefinery for 9-cis $\beta$-carotene production. Algal Res. 2020;50:102002.

25. Prieto A, Pedro Cañavate J, García-González M. Assessment of carotenoid production by Dunaliella salina in different culture systems and operation regimes. J Biotechnol. 2011;151(2):180-5. https://doi.org/10.1016/j.jbiotec.201 0.11 .011 .

26. Shah MMR, Liang Y, Cheng JJ, Daroch M. Astaxanthin-producing Green microalga Haematococcus pluvialis: from single cell to high value commercial products. Front Plant Sci. 2016;7:531.

27. Batista AP, Narcisa LG, Bandarra M, JFranco JM, Raymundo A. Comparison of microalgal biomass profiles as novel functional ingredient for food products. Algal Res. 2013;2(2):164-73. https://doi.org/10.1016/j.algal.2013.01.004.

28. Zhu Y, Zhao X, Zhang $X$, Liu H. Ao Q amino acid, structure and antioxidant properties of Haematococcus pluvialis protein hydrolysates produced by different proteases. Int J Food Sci Technol. 2020;56:185-95.

29. Tan LT. Bioactive natural products from marine cyanobacteria for drug discovery. Phytochemistry. 2007;68(7):954-79. https://doi.org/10.1016/j. phytochem.2007.01.012.

30. Sasso S, Pohnert G, Lohr M, Mittag M, Hertweck C. Microalgae in the postgenomic era: a blooming reservoir for new natural products. FEMS Microbiol Rev. 2012;36(4): 761-85. https:/doi.org/10.1111/j.1574-6976.2011.00304x.

31. Jacob-Lopes E, Maroneze MM, Deprá MC, Sartori RB, Dias RR, Zepka LQ. Bioactive food compounds from microalgae: an innovative framework on industrial biorefineries. Curr Opin Food Sci. 2019;25:1-7. https://doi.org/10.1 016/j.cofs.2018.12.003.

32. Burja AM, Banaigs B, Abou-Mansour E, Grant Burgess J, Wright PC. Marine cyanobacteria - a prolific source of natural products. Tetrahedron. 2001; 57(46):9347-77. https://doi.org/10.1016/S0040-4020(01)00931-0.

33. Suresh G, Das RK, Kaur Brar S, Rouissi T, Avalos Ramirez A, Chorfi Y, et al. Alternatives to antibiotics in poultry feed: molecular perspectives. Crit Rev Microbiol. 2018;44(3):318-35. https://doi.org/10.1080/1040841X.2 017.1373062 .

34. Becker W. Microalgae in Human and Animal Nutrition. In:Richmond A, Hu Q. editors. HandbookMicroalgal Culture. Chichester: Wiley; 2007;312-51.

35. HemaiswaryaS, Raja R, Kumar RR, Ganesan V, Anbazhagan C. Microalgae: Asustainable feed source for aquaculture. World J Microbiol Biotechnol. 2011;27: 1737-46

36. Samarakoon $\mathrm{K}$, Jeon $\mathrm{YJ}$. Bio-functionalities of proteins derived from marine algae - a review. Food Res Int. 2012;48(2):948-60. https://doi.org/10.1016/j. foodres.2012.03.013.

37. Spolaore P, Joannis-Cassan C, Duran E, Isambert A. Commercial applications of microalgae. J Biosci Bioeng. 2006;101(2):87-96. https://doi.org/10.1263/ jbb.101.87.

38. Mobin S, Alam F. Some promising microalgal species for commercial applications: a review. Energy Procedia. 2017;110:510-7. https://doi.org/10.1 016/j.egypro.2017.03.177.

39. De Morais MG, Vaz BDS, De Morais EG, Costa JAV. Biologically active metabolites synthesized by microalgae. Biomed Res Int. 2015;2015:835761.
40. Pierre G, Delattre C, Laroche C, Michaud P. Galactans and its applications. Polysaccharides Bioactivity Biotechnol. 2011:54:1075-92.

41. Markou G, Angelidaki I, Georgakakis D. Microalgal carbohydrates: an overview of the factors influencing carbohydrates production, and of main bioconversion technologies for production of biofuels. Appl Microbiol Biotechnol. 2012;96(3):631-45. https://doi.org/10.1007/s00253-012-4398-0.

42. Chacón-Lee TL, González-Mariño GE. Microalgae for "healthy" foodspossibilities and challenges. Compr Rev Food Sci Food Saf. 2010;9(6):655-75. https://doi.org/10.1111/j.1541-4337.2010.00132.x.

43. López G, Yate C, Ramos FA, Cala MP, Restrepo S, Baena S. Production of Polyunsaturated Fatty Acids and Lipids from Autotrophic, Mixotrophic and Heterotrophic cultivation of Galdieria sp. strain USBA-GBX-832. Sci Rep. 2019;9:10791.

44. Udayan A, Arumugam M, Pandey A. Nutraceuticals from algae and cyanobacteria. Algal Green Chem Recent Prog Biotechnol. 2017:65-89. https://doi.org/10.1016/B978-0-444-63784-0.00004-7.

45. Hosseini B, Nourmohamadi M, Hajipour S, Taghizadeh M, Asemi Z, Keshavarz SA, et al. The effect of Omega-3 fatty acids, EPA, and/or DHA on male infertility: a systematic review and meta-analysis. J Diet Suppl. 2019; 16(2):245-56. https://doi.org/10.1080/19390211.2018.1431753.

46. Liu J, Sommerfeld M, Hu Q. Screening and characterization of Isochrysis strains and optimization of culture conditions for docosahexaenoic acid production. Appl Microbiol Biotechnol. 2013;97(11):4785-98. https://doi. org/10.1007/s00253-013-4749-5.

47. Ma XN, Chen TP, Yang B, Liu J, Chen F. Lipid production from Nannochloropsis. Mar Drugs. 2016;14(4). https://doi.org/10.3390/md14040061.

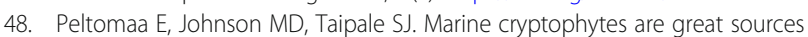
of EPA and DHA. Mar Drugs. 2018;16.

49. Stahl W, Sies H. Bioactivity and protective effects of natural carotenoids. Biochim Biophys Acta - Mol Basis Dis. 2005;1740:101-07.

50. Guedes AC, Amaro HM, Malcata FX. Microalgae as sources of carotenoids. Mar Drugs. 2011;9(4):625-44. https://doi.org/10.3390/md9040625.

51. Gille A, Trautmann A, Posten C, Briviba K. Bioaccessibility of carotenoids from Chlorella vulgaris and Chlamydomonas reinhardtii. Int J Food Sci Nutr. 2016;67(5):507-13. https://doi.org/10.1080/09637486.2016.1181158.

52. Rauytanapanit M, Janchot $K$, Kusolkumbot $P$, Sirisattha $S$, Waditee-Sirisattha $R$, Praneenararat $T$. Nutrient deprivation-associated changes in green microalga coelastrum sp. TISTR 9501RE enhanced potent antioxidant carotenoids. Mar Drugs. 2019;17.

53. Renju GL, Kurup GM, Kumari CHS. Anti-inflammatory activity of lycopene isolated from Chlorella marina on type II collagen induced arthritis in Sprague Dawley rats. Immunopharmacol Immunotoxicol. 2013;35:282-91.

54. Kim SM, Jung YJ, Kwon ON, Cha KH, Um BH, Chung D, et al. A potential commercial source of fucoxanthin extracted from the microalga Phaeodactylum tricornutum. Appl Biochem Biotechnol. 2012;166(7):1843-55. https://doi.org/10.1007/s12010-012-9602-2

55. Chen F, Li H Bin, Wong RNS, Ji B, Jiang Y Isolation and purification of the bioactive carotenoid zeaxanthin from the microalga Microcystis aeruginosa by high-speed counter-current chromatography J Chromatogr A 2005;1064: 183-186, 2, doi: https://doi.org/10.1016/j.chroma.2004.12.065.

56. Bermúdez J, Rosales N, Loreto C, Briceño B, Morales E. Exopolysaccharide, pigment and protein production by the marine microalga Chroomonas sp. in semicontinuous cultures. World J Microbiol Biotechnol. 2004;20(2):179-83. https://doi.org/10.1023/B:WIBI.0000021754.59894.4a.

57. Osterrothová K, Culka A, Němečková K, Kaftan D, Nedbalová L, Procházková L, et al. Analyzing carotenoids of snow algae by Raman microspectroscopy and high-performance liquid chromatography. Spectrochim Acta - Part A Mol Biomol Spectrosc. 2019;212:262-71. https://doi.org/10.1016/j.saa.2019.01.013.

58. Chue KT, Ten LN, Oh YK, Woo SG, Lee M, Yoo SA. Carotinoid compositions of five microalga species. Chem Nat Compd. 2012;48(1):141-2. https://doi. org/10.1007/s10600-012-0183-7

59. Takaichi S. Distributions, biosyntheses and functions of carotenoids in algae. Agro Food Ind Hi Tech. 2013;24:1

60. Ben-Amotz A, Levy Y. Bioavailability of a natural isomer mixture compared with synthetic all-trans $\beta$-carotene in human serum. Am J Clin Nutr. 1996; 63(5):729-34. https://doi.org/10.1093/ajcn/63.5.729.

61. Borowitzka LJ, Borowitzka MA. $\beta$-Carotene (Provitamin A) Production with Algae. Biotechnol Vitamins, Pigment Growth Factors. Elsevier Applied Biotechnology Series. Dordrecht: Springer; 1989. p. 5-26.

62. Borowitzka MA. Dunaliella: Biology, Production, and Markets. Handb Microalgal Cult Appl Phycol Biotechnol Second Ed. 2013. p. 359-68. 
63. Jannel S, Caro Y, Bermudes M, Petit T. Novel insights into the biotechnological production of haematococcus pluvialis-derived astaxanthin: advances and key challenges to allow its industrial use as novel food ingredient. J Mar Sci Eng. 2020;8(10):789.

64. Fabregas J, Herrero C. Vitamin content of four marine microalgae. Potential use as source of vitamins in nutrition. J Ind Microbiol. 1990;5(4):259-63. https://doi.org/10.1007/BF01569683.

65. Christaki E, Florou-Paneri P, Bonos E. Microalgae: a novel ingredient in nutrition. Int J Food Sci Nutr. 2011;62(8):794-9. https://doi.org/10.3109/0963 7486.2011 .582460 .

66. Doucha J, Lívanský K, Kotrbáček V, Zachleder V. Production of Chlorella biomass enriched by selenium and its use in animal nutrition: a review. Appl Microbiol Biotechnol. 2009;83(6):1001-8. https://doi.org/10.1007/s002 53-009-2058-9.

67. Slegers PM, Van Beveren PJM, Wijfels RH, Van Straten G, Van Boxtel AJB. Scenario analysis of large scale algae production in tubular photobioreactors. Appl Energy. 2013;105:395-406. https://doi.org/10.1016/j.a penergy.2012.12.068.

68. Skrede A, Mydland LT, Ahlstrem O, Reitan Kl, Gislered HR, Overland M. Evaluation of microalgae as sources of digestible nutrients for monogastric animals. J Anim Feed Sci. 2011;20(1):131-42. https://doi.org/10.22358/jafs/ $66164 / 2011$.

69. Abd El-Baky HH, El Baz FK, El-Baroty GS. Enhancement of antioxidant production in Spirulina platensis under oxidative stress. Acta Physiol Plant. 2009;31(3):623-31. https://doi.org/10.1007/s11738-009-0273-8.

70. Zhang D, Wan M, del Rio-Chanona EA, Huang J, Wang W, Li Y, et al. Dynamic modelling of Haematococcus pluvialis photoinduction for astaxanthin production in both attached and suspended photobioreactors. Algal Res. 2016;13:69-78. https://doi.org/10.1016/j.algal.2015.11.019.

71. Madamwar D, Kaushal A, Patel DK, Desai SN, Upadhyay K, Devkar RV. Cyanobacterial phycoerythrin purified from marine Lyngbya sp. induces apoptosis in lung carcinoma cells. Bangladesh J Pharmacol. 2015;10(4):7708. https://doi.org/10.3329/bjp.v10i4.23896.

72. Saadaoui I, Rasheed R, Abdulrahman N, Bounnit T, Cherif M, Al Jabri H, et al. Algae-derived bioactive compounds with anti-lung cancer potential. Mar. Drugs. 2020;18(4):197. https://doi.org/10.3390/md18040197.

73. Hostens M, Fievez V, Vlaeminck B, Buyse J, Leroy J, Piepers S, et al. The effect of marine algae in the ration of high-yielding dairy cows during transition on metabolic parameters in serum and follicular fluid around parturition. I Dairy Sci. 2011;94(9):4603-15. https://doi.org/10.3168/jds.2010-3899.

74. Woods VB, Fearon AM. Dietary sources of unsaturated fatty acids for animals and their transfer into meat, milk and eggs: a review. Livest Sci. 2009;126(13):1-20. https://doi.org/10.1016/j.livsci.2009.07.002.

75. González-Esquerra R, Leeson S. Alternatives for enrichment of eggs and chicken meat with omega-3 fatty acids. Can J Anim Sci. 2001;81(3):295-305. https://doi.org/10.4141/A00-092.

76. Bourre JM. Where to find omega-3 fatty acids and how feeding animals with diet enriched in omega-3 fatty acids to increase nutritional value of derived products for human: what is actually useful? J Nutr Heal Aging. 2005;9:232-42

77. Bruneel C, Lemahieu C, Fraeye I, Ryckebosch E, Muylaert K, Buyse J, et al. Impact of microalgal feed supplementation on omega-3 fatty acid enrichment of hen eggs. J Funct Foods. 2013;5(2):897-904. https://doi.org/1 0.1016/j.jf.2013.01.039.

78. Feng J, Long S, Jun ZH, geng WS, hai QG, Wang J. Comparative effects of dietary microalgae oil and fish oil on fatty acid composition and sensory quality of table eggs. Poult Sci. 2020;99(3):1734-43. https://doi.org/10.1016/j. psj.2019.11.005.

79. Fredriksson S, Elwinger K, Pickova J. Fatty acid and carotenoid composition of egg yolk as an effect of microalgae addition to feed formula for laying hens. Food Chem. 2006;99(3):530-7. https://doi.org/10.1016/j.foodchem.2 005.08.018.

80. Herber SM, Van Elswyk ME. Dietary marine algae promotes efficient deposition of n-3 fatty acids for the production of enriched Shell eggs. Poult Sci. 1996;75(12):1501-7. https://doi.org/10.3382/ps.0751501.

81. Moran CA, Morlacchini M, Keegan JD, Fusconi G. Increasing the Omega-3 content of Hen's eggs through dietary supplementation with Aurantiochytrium limacinum microalgae: effect of inclusion rate on the temporal pattern of Docosahexaenoic acid enrichment, efficiency of transfer, and egg characteristics. J Appl Poult Res. 2019;28(2):329-38. https:// doi.org/10.3382/japr/pfy075.
82. Ginzberg A, Cohen M, Sod-Moriah UA, Shany S, Rosenshtrauch A, Arad S. Chickens fed with biomass of the red microalga Porphyridium sp. have reduced blood cholesterol level and modified fatty acid composition in egg yolk. J Appl Phycol. 2000;12(3/5):325-30. https:/doi.org/10.1023/A:1008102622276.

83. Barclay W, Abril R, Abril P, Weaver C, Ashford A. Production of docosahexaenoic acid from microalgae and its benefits for use in animal feeds. World Rev Nutr Diet. 1998;83:61-76. https://doi.org/10.1159/ 000059671.

84. Cherian G, Wolfe FW, Sim JS. Dietary oils with added tocopherols: effects on egg or tissue tocopherols, fatty acids, and oxidative stability. Poult Sci. 1996; 75(3):423-31. https://doi.org/10.3382/ps.0750423.

85. Kassis N, Drake SR, Beamer SK, Matak KE, Jaczynski J. Development of nutraceutical egg products with omega-3-rich oils. LWT - Food Sci Technol. 2010;43(5):777-83. https://doi.org/10.1016/j.lwt.2009.12.014.

86. Englmaierová M, Skrivan M, Bubancová I. A comparison of lutein, spraydried Chlorella, and synthetic carotenoids effects on yolk colour, oxidative stability, and reproductive performance of laying hens. Czech J Anim Sci. 2013;58(9):412-9. https://doi.org/10.17221/6941-CJAS.

87. Connor WE. Importance of n-3 fatty acids in health and disease. Am J Clin Nutr. 2000;71(1):171S-5S. https://doi.org/10.1093/ajcn/71.1.171S.

88. Wallace JMW, Mccabe AJ, Robson PJ, Keogh MK, Murray CA, Kelly PM, et al. Bioavailability of n-3 polyunsaturated fatty acids (PUFA) in foods enriched with microencapsulated fish oil. Ann Nutr Metab. 2000;44(4):157-62. https:// doi.org/10.1159/000012839.

89. Scott TW, Cook LJ, Mills SC. Protection of dietary polyunsaturated fatty acids against microbial hydrogenation in ruminants. J Am Oil Chem Soc. 1971; 48(7):358-64. https://doi.org/10.1007/BF02890762.

90. Wachira AM, Sinclair LA, Wilkinson RG, Enser M, Wood JD, Fisher AV. Effects of dietary fat source and breed on the carcass composition, $n-3$ polyunsaturated fatty acid and conjugated linoleic acid content of sheep meat and adipose tissue. Br J Nutr. 2002;88(6):697-709. https://doi.org/10.1 079/BJN2002727.

91. Shingfield KJ, Ahvenjärvi S, Toivonen V, Vanhatalo A, Huhtanen P, Griinari $J M$. Effect of incremental levels of sunflower-seed oil in the diet on ruminal lipid metabolism in lactating cows. Br J Nutr. 2008;99(5):971-83. https://doi. org/10.1017/S0007114507853323.

92. Elmore JS, Mottram DS, Enser M, Wood JD. The effects of diet and breed on the volatile compounds of cooked lamb. Meat Sci. 2000:55(2):149-59. https://doi.org/10.1016/S0309-1740(99)00137-0.

93. Lum KK, Kim J, Lei XG. Dual potential of microalgae as a sustainable biofuel feedstock and animal feed. J Anim Sci Biotechnol. 2013;4(1):53. https://doi. org/10.1186/2049-1891-4-53.

94. Kalbe C, Priepke A, Nürnberg G, Dannenberger D. Effects of long-term microalgae supplementation on muscle microstructure, meat quality and fatty acid composition in growing pigs. J Anim Physiol Anim Nutr (Berl). 2019;103(2):574-82. https://doi.org/10.1111/.jpn.13037.

95. Arney B, Liu W, Forster IP, McKinley RS, Pearce CM. Feasibility of dietary substitution of live microalgae with spray-dried Schizochytrium sp. or Spirulina in the hatchery culture of juveniles of the Pacific geoduck clam (Panopea generosa). Aquaculture. 2015;444:117-33.

96. Toyomizu M, Sato K, Taroda H, Kato T, Akiba Y. Effects of dietary Spirulina on meat colour in muscle of broiler chickens. Br Poult Sci. 2001;42(2):197202. https://doi.org/10.1080/00071660120048447.

97. Kang HK, Salim HM, Akter N, Kim DW, Kim JH, Bang HT, et al. Effect of various forms of dietary Chlorella supplementation on growth performance, immune characteristics, and intestinal microflora population of broiler chickens. J Appl Poult Res. 2013;22(1):100-8. https://doi.org/10.3382/japr.2 012-00622.

98. Swiatkiewicz S, Arczewska-Włosek A, Józefiak D. Application of microalgae biomass in poultry nutrition. Worlds Poult Sci J. 2015;71:663-72.

99. Lamminen M, Halmemies-Beauchet-Filleau A, Kokkonen T, Jaakkola S, Vanhatalo A. Different microalgae species as a substitutive protein feed for soya bean meal in grass silage based dairy cow diets. Anim Feed Sci Technol. 2019;247:112-26. https://doi.org/10.1016/j.anifeedsci.2018.11.005.

100. Santos JEP, Bilby TR, Thatcher WW, Staples CR, Silvestre FT. Long chain fatty acids of diet as factors influencing reproduction in cattle. Reprod Domest Anim. 2008;43:23-30. https://doi.org/10.1111/j.1439-0531.2008.01139.x.

101. Wullepit N, Hostens M, Ginneberge C, Fievez V, Opsomer G, Fremaut D, et al. Influence of a marine algae supplementation on the oxidative status of plasma in dairy cows during the periparturient period. Prev Vet Med. 2012;103(4):298-303. https://doi.org/10.1016/j.prevetmed.2011.09.007. 
102. Elgersma A, Ellen G, Van Der Horst H, Boer H, Dekker PR, Tamminga S. Quick changes in milk fat composition from cows after transition from fresh grass to a silage diet. Anim Feed Sci Technol. 2004;117(1-2):13-27. https://doi. org/10.1016/j.anifeedsci.2004.08.003.

103. Stamey JA, Shepherd DM, de Veth MJ, Corl BA. Use of algae or algal oil rich in n-3 fatty acids as a feed supplement for dairy cattle. J Dairy Sci. 2012; 95(9):5269-75. https://doi.org/10.3168/jds.2012-5412.

104. Papadopoulos G, Goulas C, Apostolaki E, Abril R. Effects of dietary supplements of algae, containing polyunsaturated fatty acids, on milk yield and the composition of milk products in dairy ewes. J Dairy Res. 2002;69(3): 357-65. https://doi.org/10.1017/S0022029902005599.

105. Boeckaert C, Vlaeminck B, Dijkstra J, Issa-Zacharia A, Van Nespen T, Van Straalen W, et al. Effect of dietary starch or micro algae supplementation on rumen fermentation and milk fatty acid composition of dairy cows. J Dairy Sci. 2008;91(12):4714-27. https://doi.org/10.3168/jds.2008-1178.

106. Glover KE, Budge S, Rose M, Rupasinghe HPV, MacLaren L, Green-Johnson J, et al. Effect of feeding fresh forage and marine algae on the fatty acid composition and oxidation of milk and butter. J Dairy Sci. 2012;95(6):2797809. https://doi.org/10.3168/jds.2011-4736.

107. Sukenik A, Zmora O, Carmeli Y. Biochemical quality of marine unicellular algae with special emphasis on lipid composition. II Nannochloropsis sp. Aquaculture. 1993;117:313-26.

108. Kairenius $P$, Ärölä A, Leskinen $H$, Toivonen V, Ahvenjärvi S, Vanhatalo A, et al. Dietary fish oil supplements depress milk fat yield and alter milk fatty acid composition in lactating cows fed grass silage-based diets. J Dairy Sci. 2015; 98(8):5653-71. https://doi.org/10.3168/jds.2015-9548.

109. Moate PJ, Williams SRO, Hannah MC, Eckard RJ, Auldist MJ, Ribaux BE, et al. Effects of feeding algal meal high in docosahexaenoic acid on feed intake, milk production, and methane emissions in dairy cows. J Dairy Sci. 2013; 96(5):3177-88. https://doi.org/10.3168/jds.2012-6168.

110. Pourabedin M, Zhao X. Prebiotics and gut microbiota in chickens. FEMS Microbiol Lett. 2015;362:122.

111. De Jesus Raposo MF, De Morais AMMB, De Morais RMSC. Emergent sources of prebiotics: seaweeds and microalgae. Mar Drugs. 2016;14(2):27. https:// doi.org/10.3390/md14020027.

112. Gupta C. Prebiotic efficiency of blue Green algae on probiotics microorganisms. J Microbiol Exp. 2017;4:00120.

113. Jacobsen C, Hartvigsen K, Lund P, Thomsen MK, Skibsted LH, Hølmer G, et al. Oxidation in fish oil-enriched mayonnaise: 4. Effect of tocopherol concentration on oxidative deterioration. Eur Food Res Technol. 2001;212(3): 308-18. https://doi.org/10.1007/s002170000251.

114. Lee S, Faustman C, Djordjevic D, Faraji H, Decker EA. Effect of antioxidants on stabilization of meat products fortified with $n-3$ fatty acids. Meat Sci. 2006;72(1):18-24. https://doi.org/10.1016/j.meatsci.2005.05.022.

115. Sakata H. Possibility of the treatment of herpes simplex keratitis with fluorescent antibody combined with argon laser irradiation. Study on "in vitro" herpes simplex virus. J Japanese Ophthalmol Soc. 1977;81:1279-88.

116. Frankel EN. Lipid oxidation. Prog Lipid Res. 1980;19(1-2):1-22. https://doi. org/10.1016/0163-7827(80)90006-5.

117. Venkateshwarlu G, Let MB, Meyer AS, Jacobsen C. Chemical and Olfactometric characterization of volatile flavor compounds in a fish oil enriched Milk emulsion. J Agric Food Chem. 2004;52(2):311-7. https://doi. org/10.1021/jf034833v.

118. Tibbetts SM, Patelakis SJJ, Whitney-Lalonde CG, Garrison LL, Wall CL, MacQuarrie SP. Nutrient composition and protein quality of microalgae meals produced from the marine prymnesiophyte Pavlova sp. 459 masscultivated in enclosed photobioreactors for potential use in salmonid aquafeeds. J Appl Phycol. 2020;32(1):299-318. https://doi.org/10.1007/s1 0811-019-01942-2.

119. Evans AM, Smith DLC, Moritz JS. Effects of algae incorporation into broiler starter diet formulations on nutrient digestibility and 3 to $21 \mathrm{~d}$ bird performance. J Appl Poult Res. 2015;24(2):206-14. https://doi.org/10.3382/japr/pfv027.

120. Moheimani NR, Vadiveloo A, Ayre JM, Pluske JR. Nutritional profile and in vitro digestibility of microalgae grown in anaerobically digested piggery effluent. Algal Res. 2018;35:362-9. https://doi.org/10.1016/j.algal.2018.09.007.

121. Barros Al, Gonçalves AL, Simões M, Pires JCM. Harvesting techniques applied to microalgae: a review. Renew Sust Energ Rev. 2015;41:1489-500. https://doi.org/10.1016/j.rser.2014.09.037.

122. La Barre S, Potin P, Leblanc C, Delage L. The halogenated metabolism of brown algae (phaeophyta), its biological importance and its environmental significance. Mar Drugs. 2010;8(4):988-1010. https:/doi.org/10.3390/md8040988.
123. Costa JAV, Freitas BCB, Santos TD, Mitchell BG, Morais MG. Open pond systems for microalgal culture. Biofuels from Algae. 2019 p 199-223.

124. Norsker NH, Barbosa MJ, Vermuë MH, Wijffels RH. Microalgal production - a close look at the economics. Biotechnol Adv. 2011;29:24-7.

125. Fu W, Gudmundsson S, Wichuk K, Palsson S, Palsson BO, Salehi-Ashtiani K, et al. Sugar-stimulated CO 2 sequestration by the green microalga Chlorella vulgaris. Sci Total Environ. 2019;654:275-83. https://doi.org/10.1016/j. scitotenv.2018.11.120.

126. Wen X, Du K, Wang Z, Peng X, Luo L, Tao H, et al. Effective cultivation of microalgae for biofuel production: a pilot-scale evaluation of a novel oleaginous microalga Graesiella sp. WBG-1. Biotechnol Biofuels. 2016;9(1): 123. https://doi.org/10.1186/s13068-016-0541-y.

127. Zittelli GC, Biondi N, Rodolfi L, Tredici MR. Photobioreactors for Mass Production of Microalgae. Handb Microalgal Cult Appl Phycol Biotechnol Second Ed. 2013. p. 225-66.

128. Acién Fernández FG, Fernández Sevilla JM, MolinaGrima E. Photobioreactors for the production of microalgae. Rev Environ Sci Biotechnol. 2013;12(2): $131-51$

129. Tredici MR, Rodolfi L, Biondi N, Bassi N, Sampietro G. Techno-economic analysis of microalgal biomass production in a 1-ha Green Wall panel (GWP®) plant. Algal Res. 2016:19:253-63. https://doi.org/10.1016/.algal.2016.09.005.

130. Wigmosta MS, Coleman AM, Skaggs RJ, Huesemann MH, Lane LJ. National microalgae biofuel production potential and resource demand. Water Resour Res. 2011:47:W0OH04.

131. Barad M. Anatomical, molecular, and cellular substrates of fear extinction. Fear Learn. From basic Process. to Clin. Implic. 2007.

132. Khan MI, Shin JH, Kim JD. The promising future of microalgae: current status, challenges, and optimization of a sustainable and renewable industry for biofuels, feed, and other products. Microb Cell Fact. 2018;17:36.

133. Das $\mathrm{P}$, Thaher $\mathrm{M}$, Khan $\mathrm{S}$, AbdulQuadir M, Al-Jabri H. The effect of culture salinity on the harvesting of microalgae biomass using pilot-scale tangential-flow-filter membrane. Bioresour Technol. 2019:293:122057. https://doi.org/10.1016/j.biortech.2019.122057.

134. Das $P$, Thaher MI, Hakim MAQMA, Al-Jabri HMSJ, Alghasal GSHS. A comparative study of the growth of Tetraselmis sp. in large scale fixed depth and decreasing depth raceway ponds. Bioresour Technol. 2016;216: 114-20. https://doi.org/10.1016/j.biortech.2016.05.058.

135. Vandamme D, Foubert I, Muylaert K. Flocculation as a low-cost method for harvesting microalgae for bulk biomass production. Trends Biotechnol. 2013:31(4):233-9. https://doi.org/10.1016/j.tibtech.2012.12.005.

136. Lin JH, Lee DJ, Chang JS. Lutein production from biomass: Marigold flowers versus microalgae. Bioresour Technol. 2015;184:421-8. https://doi.org/10.101 6/j.biortech.2014.09.099.

137. Ambati RR, Gogisetty D, Aswathanarayana RG, Ravi S, Bikkina PN, Bo L, et al. Industrial potential of carotenoid pigments from microalgae: current trends and future prospects. Crit Rev Food Sci Nutr. 2019;59(12):1880-902. https:// doi.org/10.1080/10408398.2018.1432561.

138. Peng K, Li J, Jiao K, Zeng X, Lin L, Pan S, et al. The Bioeconomy of Microalgal Biofuels. Green Energy Technol. 2018. p. 157-169.

139. Dębowski M, Zieliński M, Kazimierowicz J, Kujawska N, Talbierz S. Microalgae cultivation technologies as an opportunity for bioenergetic system development—advantages and limitations. Sustain. 2020;12:9980.

140. Trivedi T, Jain D, Mulla NSS, Mamatha SS, Damare SR, Sreepada RA, et al. Improvement in biomass, lipid production and biodiesel properties of a euryhaline Chlorella vulgaris NIOCCV on mixotrophic cultivation in wastewater from a fish processing plant. Renew Energy. 2019;139:326-35. https://doi.org/10.1016/j.renene.2019.02.065.

141. Saadaoui I, Al Ghazal G, Bounnit T, Al Khulaifi F, Al Jabri H, Potts M. Evidence of thermo and halotolerant Nannochloris isolate suitable for biodiesel production in Qatar culture collection of cyanobacteria and microalgae. Algal Res. 2016;14:39-47. https://doi.org/10.1016/j.algal.2015.12.019.

142. Saadaoui I, Sedky R, Rasheed R, Bounnit T, Almahmoud A, Elshekh A, et al. Assessment of the algae-based biofertilizer influence on date palm (Phoenix dactylifera L.) cultivation. J Appl Phycol. 2019;31:457-63.

143. Rasheed R, Saadaoui I, Bounnit T, Cherif M, Al Ghazal G, Al JH. Sustainable food production and nutraceutical applications from Qatar desert chlorella sp. (chlorophyceae). Animals. 2020;10:1-16.

144. Saadaoui I, Bounnit T, Muraikhi M, Rasheed R, Alghasal G, Al JH. Improvement of both lipid and biomass productivities of Qatar Chlorocystis isolate for biodiesel production and food security. Phycol Res. 2018;66(3): 182-8. https://doi.org/10.1111/pre.12217. 
145. Bounnit T, Saadaoui I, Rasheed R, Schipper K, Al MM, Al JH. Sustainable production of Nannochloris atomus biomass towards biodiesel production Sustain. 2020;12:2008.

146. Schipper K, Fortunati F, Oostlander PC, Al Muraikhi M, Al Jabri HMSJ, Wijffels $\mathrm{RH}$, et al. Production of phycocyanin by Leptolyngbya sp in desert environments. Algal Res. 2020:47:101875.

147. Das P, Thaher M, AbdulQuadir M, Khan S, Chaudhary A, Al-Jabri H. Longterm semi-continuous cultivation of a halo-tolerant Tetraselmis sp. using recycled growth media. Bioresour Technol. 2019;276:35-41. https://doi.org/1 0.1016/j.biortech.2018.12.108

Ready to submit your research? Choose BMC and benefit from:

- fast, convenient online submission

- thorough peer review by experienced researchers in your field

- rapid publication on acceptance

- support for research data, including large and complex data types

- gold Open Access which fosters wider collaboration and increased citations

- maximum visibility for your research: over $100 \mathrm{M}$ website views per year

At BMC, research is always in progress.

Learn more biomedcentral.com/submissions 